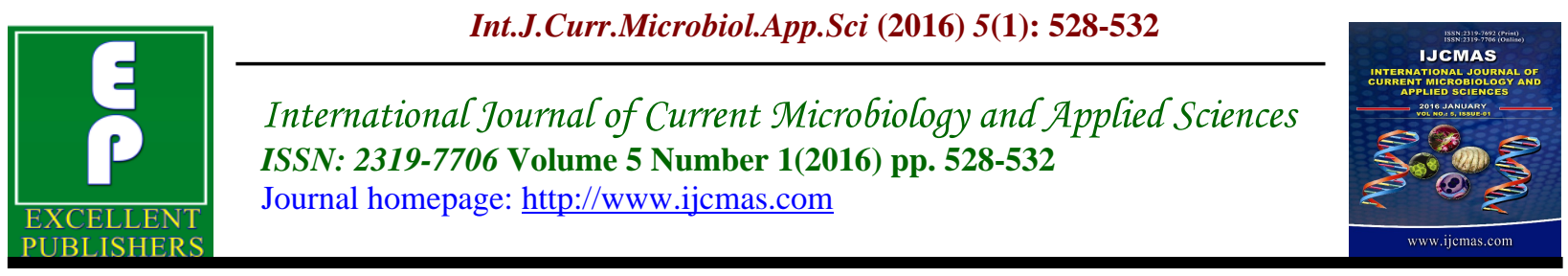

Original Research Article

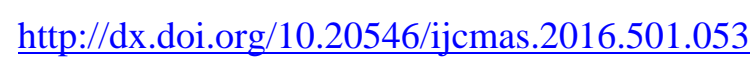

\title{
Decolorization of Reactive Dyes by Immobilized Bacterial Cells from Textile Effluents
}

\author{
K. Suganya and K. Revathi* \\ Department of Zoology, Ethiraj College for Women, Chennai, India \\ *Corresponding author
}

Keywords

Textile effluent, P.Putida, B.Licheniformis, Immobilization

Article Info

Accepted:

22 December 2015 Available Online: 10 January 2016

\section{A B S T R A C T}

Textile effluent is said to be one of the major sources of water pollution which contains various chemicals and hazardous wastes that contaminate the receiving water bodies. This study was conducted to study the efficiency of immobilized P.putida and B.licheniformis on decolorization of reactive dyes (RR 195, RO 72, RY 17, RB 36). Immobilization was done using sodium alginate and polyacrylamide gel beads both at static and shaken conditions. Sodium alginate immobilized bacteria exhibited maximum decolorization than that of polyacrylamide gel bead method.

\section{Introduction}

The quality of life on earth is directly or indirectly linked to the overall quality of the environment. Due to rapid increase in population, there is vast increase in textile industries which has shown a significant use of synthetic complex organic dyes as the coloring material. It has been found that these industries discharge around 28,000 tons of dyes worldwide every year into the environment (Tom Sinoy et al., 2011) Out of which a large number of dyes are azo compounds ( $-\mathrm{N}=\mathrm{N}-)$ linked by an azo bridge and are used by a number of industries because of their cost effectiveness in synthesis compared to natural dyes (Saratale et al., 2010).
Azo dyes are widely used in food, pharmaceutical, paper, printing, leather and cosmetics (Asamudo et al., 2005). These represent the largest and most versatile class of dyes which accounts for more than $50 \%$ of the dyes produced annually. Taking into account the volume and composition of effluents, the textile wastewater is rated as the most polluting among all in industrial sectors (Sen \& Demirer, 2003). The wastewater released from textile industry is a complex mixture of many polluting substances comprising a wide range of heavy metals and organochlorides based waste pesticides (Correia et al., 1994). 
The effluents from textiles significantly affect the photosynthetic activity of aquatic life by impeding light penetration, damages the quality of the receiving streams thus disturbing the food chain of aquatic ecosystem (Aksu et al., 2007). In recent times, government legislation is becoming more stringent especially in developed/developing countries regarding the removal of dyes from industrial effluents. There are many physico-chemical techniques in removal of color from wastewater such as coagulation, flocculation, membrane filtration, precipitation, adsorption etc. But these methods have their own drawbacks of being economically unfeasible, unable to remove the recalcitrant azo dyes inturn generating a significant amount of sludge that may cause secondary pollution problems (Anjaneyulu et al., 2005). The biological decolorization and degradation of synthetic dyes has been of considerable interest since it is ecofriendly, cheap and produces less amount of sludge (Moosvi et al., 2005; Kalyani et al., 2009). The ubiquitous nature of microorganisms makes them an invaluable tool in treatment of wastewater from industries (Olukanni et al., 2006)

Recently the application of immobilized cells for biosorption of dyes has been gaining attention in the field of wastewater decolorization. Many researchers have studied the effect of immobilized whole cells and enzymes on decolorization characteristics since immobilization provides distinct stability over free cells $(\mathrm{Ha}$ et al., 2009). Immobilization of the microbial cells offers a great potential in various bioremediation processes. Intensive research has been carried out in the field of immobilization of cells since last two decades. Therefore the present study is directed to investigate the decolorization ability of free and immobilized cells of
B.licheniformis and P.putida on reactive azo dyes.

\section{Materials and Methods}

\section{Sample Site}

The samples were collected from textile effluent water from Erode effluent discharge points located in Kaveri river, Karunkalpalayam, India.

\section{Sample Collection}

Samples were collected in screw capped sterilized bottles aseptically and transported to the laboratory in an ice bucket.

\section{Dyes and Media}

To see the degrading efficiency of isolated bacteria, four different commercially available dyes namely Reactive Red 195, Reactive Yellow 17, Reactive Orange 72, and Reactive Blue 36 were used in this study. All chemicals and dyes were of highest purity and of analytical grade.

\section{Isolation of Bacteria}

Bacillus licheniformis and Pseudomonas putida were isolated from the textile effluent samples. Bacteria were isolated through serial dilution and streak plate method on Nutrient Agar. Identification of bacteria was done by colony, cellular morphological characters and performing biochemical tests following Bergey's manual of Systematic Bacteriology.

\section{Decolorization by Immobilized Whole Bacterial Cells}

In the present study, the efficiency of isolated bacteria to decolorize the reactive dyes RR 195, RO 72, RY 17, and RB 36 
immobilized on polyacrylamide gel beads and sodium alginate were evaluated. Initially, percentage of degradation of bacterial isolates against the four reactive dyes was studied in liquid media. P.putida against RR 195 and RO 72 showed efficient decolorization. B.licheniformis produced significant color reduction with RY 17 and RB 36.

Hence immobilization studies were carried out with P.putida (RR 195 and RO 72) and B.licheniformis (RY 17, RB 36) The dye decolorizing potential was determined at both static $(0 \mathrm{rpm})$ and agitated conditions $(50 \mathrm{rpm}, 100 \mathrm{rpm})$. Immobilization of the isolate was carried out using $4 \%$ sodium alginate adopting the method of Bettman \& Rehm (1984). Polyacrylamide gel entrapment of cells was performed according to the method of Jonathan, 1988.

\section{Results and Discussion}

P.putida and B.licheniformis were identified and isolated from textile effluent sample.
The efficiency of immobilized bacterial cells to decolorize the reactive dyes was investigated at static and agitated conditions.

Table 1 shows that at static conditions P.putida against RR 195 showed 91\% degradation. Sodium alginate embedded cells gave maximum decolorization (96.59\%) than polyacrylamide immobilization (93.58\%). At 50 and 100 rpm the decolorizing activity gradually decreased.

Table 2 shows the percentage of decolorization of RO 72 by immobilized P.putida. Above $90 \%$ degradation of RO 72 was recorded at static conditions by free cells. Under agitated conditions of $50 \mathrm{rpm}$ the rate of decolorization decreased gradually. It was noted that sodium alginate immobilized cells gave maximum color reduction compared to polyacrylamide. There was a decrease in decolorizing activity when immobilization was done at $100 \mathrm{rpm}$.

Table.1 Decolorization of RR 195 by Immobilized P.Putida

\begin{tabular}{|c|c|c|c|}
\hline \multirow{2}{*}{ Immobilization types } & \multicolumn{3}{|c|}{ Relative specific decolorization rate (\%) } \\
\cline { 2 - 4 } & 0 rpm (static)* & $\mathbf{5 0}$ rpm* & 100 rpm* \\
\hline Free cells & $91.80 \pm 0.66$ & $29.66 \pm 1.73$ & $25.00 \pm 1.20$ \\
\hline PAA immobilized cells & $93.58 \pm 0.70$ & $67.33 \pm 1.76$ & $61.66 \pm 4.72$ \\
\hline SA immobilized cells & $96.59 \pm 0.53$ & $84.33 \pm 2.33$ & $62.00 \pm 2.33$ \\
\hline
\end{tabular}

* Values represent mean of triplicate experiments along with standard error (Mean \pm SE)

Table.2 Decolorization of RO 72 by Immobilized P.Putida

\begin{tabular}{|c|c|c|c|}
\hline \multirow{2}{*}{ Types } & \multicolumn{3}{|c|}{ Relative specific decolorization rate (\%) } \\
\hline & 0 rpm (static)* & 50 rpm* & $100 \mathrm{rpm} *$ \\
\hline Free cells & $92.07 \pm 0.81$ & $30.00 \pm 4.04$ & $30.33 \pm 1.45$ \\
\hline PAA immobilized cells & $93.01 \pm 0.46$ & $66.00 \pm 6.02$ & $42.00 \pm 4.35$ \\
\hline SA immobilized cells & $96.40 \pm 0.95$ & $87.66 \pm 2.40$ & $51.00 \pm 7.93$ \\
\hline
\end{tabular}


Table.3 Decolorization of RY 17 by Immobilized B.Licheniformis

\begin{tabular}{|c|c|c|c|}
\hline \multirow{2}{*}{ Types } & \multicolumn{3}{|c|}{ Relative specific decolorization rate (\%) } \\
\cline { 2 - 4 } & $\mathbf{0 ~ r p m}$ (static)* & $\mathbf{5 0} \mathbf{~ r p m *}$ & $\mathbf{1 0 0} \mathbf{~ r p m} *$ \\
\hline Free cells & $85.03 \pm 0.84$ & $34.33 \pm 0.66$ & $32.66 \pm 2.02$ \\
\hline PAA immobilized cells & $88.63 \pm 0.50$ & $71.66 \pm 0.88$ & $48.66 \pm 3.17$ \\
\hline SA immobilized cells & $91.66 \pm 0.58$ & $87.00 \pm 2.00$ & $55.66 \pm 5.17$ \\
\hline
\end{tabular}

* Values represent mean of triplicate experiments along with standard error (Mean $\pm \mathrm{SE}$ )

Table.4 Decolorization of RB 36 by Immobilized B.Licheniformis

\begin{tabular}{|c|c|c|c|}
\hline \multirow{2}{*}{ Type of immobilization } & \multicolumn{3}{|c|}{ Relative specific decolorization rate (\%) } \\
\cline { 2 - 4 } & $\mathbf{0 ~ r p m ~ ( s t a t i c ) *}$ & $\mathbf{5 0} \mathbf{~ r p m}$ & $\mathbf{1 0 0} \mathbf{~ r p m} *$ \\
\hline Free cells & $90.77 \pm 0.53$ & $39.33 \pm 1.76$ & $36.66 \pm 1.20$ \\
\hline PAA immobilized cells & $92.12 \pm 0.76$ & $78.33 \pm 2.40$ & $55.33 \pm 1.85$ \\
\hline SA immobilized cells & $96.99 \pm 1.43$ & $84.66 \pm 1.66$ & $62.33 \pm 2.96$ \\
\hline
\end{tabular}

* Values represent mean of triplicate experiments along with standard error (Mean \pm SE)

In recent times, the application of immobilized cell has been receiving increased attention in the field of wastewater decolorization since this method not only simplifies separation and recovery of immobilized bacteria and the binding agent but also makes the application reusable, which reduces the overall cost. On the whole, immobilized cells are more tolerant to local perturbations like changes in temperature, $\mathrm{pH}$ and presence of inhibitor compounds (Tallur et al., 2009). It has been stated that sodium alginate is a suitable matrix material because it is non-toxic and the method used for its gelation is mild towards the microorganisms (Sriamornsak, 1998).

Similar trend was observed with immobilized B.licheniformis against RY 17 and RB 36 (Tables 3 and 4). In all cases, sodium alginate immobilized cells showed maximum color reduction and static conditions were found suitable for decolorization than that of 50 and $100 \mathrm{rpm}$. This was similar to the results obtained by Satheesh et al., 2013 in which significance of static conditions for better decolorization has been highlighted.
To conclude, the present study reveals that P.putida and B.licheniformis immobilized in sodium alginate at static condition is promising for its application in biodegradation of the reactive dyes in textile effluents.

\section{References}

Anjaneyulu, Y., Sreedhara, N. \& Raji, D.S.S. 2005. Decolourization of industrial effluents- available methods and emerging technologies: A Review. Environ. Sci. Biotechnol., 4: 245-273.

Aksu, Z., Kilic, N., Ertugrul, V. \& Donmez, G. 2007. Inhibitory effects of chromium (VI) and Remazol black on chromium (VI) and dyestuff removals by Trametes versicolor. Enz. Microbial Technol., 40:1167-1174.

Asamudo, N.U., Daba, A.S. \& Ezeronyel, O.U. 2005. Bioremediation of textile effluent using Phanerochaete chrysosporium. Afr. J. Biotechnol., 4: 1548-1553.

Bergey's Manual. Wiliams \& Wilkins, Baltimore. USA. 1984. Bergey's Manual of Systemic Bacteriology.

Bettman, H. \& Rehm, H.J. 1984. 
Degradation of phenol by polymer entrapped microorganisms. Appl. Microbiol. Biotechnol., 20 (5): 285290.

Correia, V.M., Stephenson, T. \& Judd, S.J. 1994. Characterization of textile waste waters- A review, Environ.Technol., 15: 917-929.

Ha, J., Engler, C.R. \& Wild, J.R. 2009. Biodegradation of coumaphos, chlorferon and diethylthiophosphate using bacteria immobilized in Caalginate gel beads. Biores. Technol., 100: 1138-1142.

Jonathan, W. 1988. Methods of immobilization of microbial cells. $J$. Microbiol. Meth., 8:91-102.

Kalyani, D.C., Telke, A.A., Dhanve, R.S. \& Jadhav, J.P. 2009. Ecofriendly biodegradation and detoxification of Reactive Red 2 textile dye newly isolated Pseudomonas sp. SUK 1. J. Hazard. Mater., 163: 735-742.

Moosvi, S., Keharia, H. \& Madamwar, D. 2005. Decolorization of textile dye reactive violet 5 by a newly isolated bacterial consortium RVM 11.1. World. J. Microbiol. Biotechnol., 21: 667-672.

Olukanni, O.D., Osuntoki, A.A. \& Gbenle, G.O. 2006. Textile effluent biodegradation potentials of textile effluent-adapted and non-adapted bacteria. Afr. J. Biotechnol., 5(20):
1980-1984.

Saratale, R.G., Saratale, G.D., Chang, J.S. \& Govindwar, S.P. 2010. Decolorization and biodegradation of reactive dyes and dye wastewater by a developed bacterial consortium. Biodegrad., 21: 999-1015.

Satheesh, S., Mohandass, C., Vijay Raj, A.S., Rajasabapathy, R., \& Mohan, A. Dhale. 2013. Multiple approaches towards decolourization and reuse of textile dye (VB-B) by marine bacterium Shewanells decolorationis. Water. Air. Soil. Pollut., 224(4): 1500.

Sen, S. \& Demirer, G.N. 2003. Anaerobic treatment of synthetic textile wastewater containing a reactive azo dye. J. Environ. Eng., 129: 595-601.

Sriamornsak, P. 1998. Preliminary investigation of some polysaccharides as a carrier for cell entrapment. Eur. J. Phar. Biopharm., 46: 233-236.

Tallur, P.N., Megadi, V.B. \& Ninnekar, H.Z. 2009. Biodegradation of p-cresol by immobilized cells of Bacillus sp. strain PHN 1. Biodegrad., 20: 79-83.

Tom Sinoy, E.S., Anuradha Mohan, D. \& Shaikh, H. 2011. Biodegradation of textile dyes by Pseudomonas $s p$ and E.coli. VSRD-TNTJ., 2: 238-248.

Zollinger, H. 1987. Colour chemistrysynthesis, properties and applications of organic dyes and pigments, $(\mathrm{VCH}$, New York), 82.

\section{How to cite this article:}

Suganya, K., and Revathi, K. 2016. Decolorization of Reactive Dyes by Immobilized Bacterial Cells from Textile Effluents. Int.J.Curr.Microbiol.App.Sci. 5(1): 528-532 http://dx.doi.org/10.20546/ijcmas.2016.501.053 